\title{
Impact of Macroeconomic Factors on Underpricing: Case of Indonesia Stock Exchange
}

\author{
Aulia Amin Nasution¹, Ali Mutasowifin²
}

1,2IPB University, Indonesia

A R T I C L E I N F O

Article History:

Received

Revised

Publish

\section{Keywords:}

Initial Public Offering, Macroeconomy, Stock Market, Underpricing

DOI:

\begin{abstract}
The stock market is one of the alternatives chosen by companies to meet their funding needs. The first offering of a company's shares through the stock market to investors is called an Initial Public Offering. At the time of initial public offering, underpricing often occurs when the initial stock price on the primary market is lower than the stock price on the secondary market which will disadvantage the company because the collected funds are not maximum. This research aims to analyze the effect of macroeconomic factors on underpricing in companies conducting IPOs listed on the Indonesia Stock Exchange from 2010 to 2020. Using Regression Linear Analyze we found that macroeconomic variables as Inflation, IDX Composite Index, and GDP significantly affect underpricing on IPO in Indonesia Stock Exchange for 2010 to 2020.
\end{abstract}

*Corresponding author: alimu@apps.ipb.ac.id 


\section{INTRODUCTION}

The capital market according to UU number 8 of 1995 is an activity related to public offerings and securities trading, public companies related to securities issued by them, and institutions and professions related to securities. One of the functions of the capital market is business funding through an Initial Public Offering (IPO) by obtaining funds from the public (investors). Initial Public Offering (IPO) is one of the right choices for companies to get additional funds, especially for expansion. business or company operations (Larasati, 2013) The number of companies conducting initial public offerings in Indonesia itself

has fluctuated as shown in

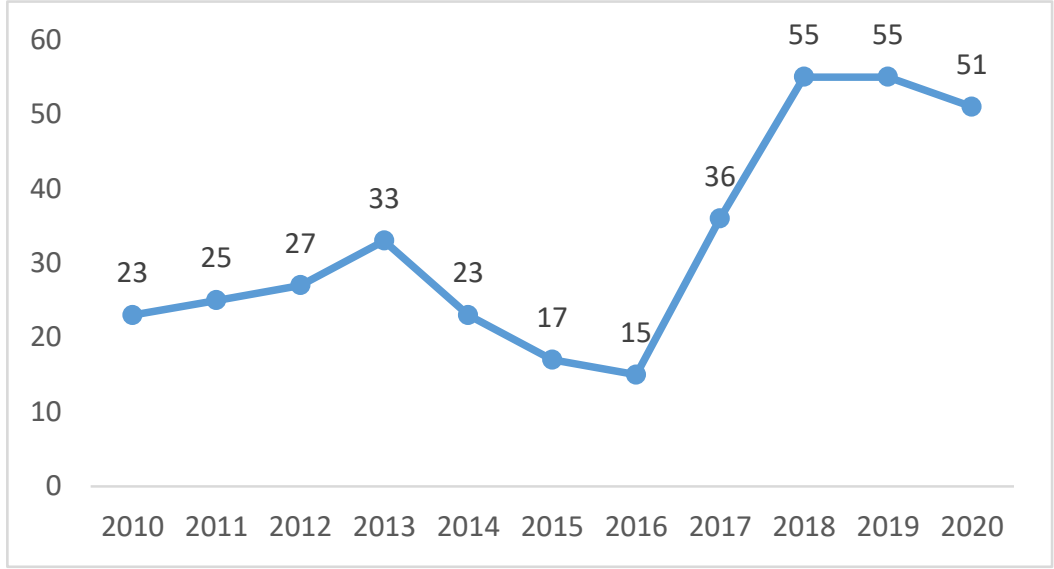

from time to time, Figure 1 below.

Figure. 1 Numbers of IPO in Indonesia from 2010 to 2020

Source : IPO Historic Data, E-bursa (2010-2020)

The data shows that the number of companies conducting IPOs increased from 2010 to 2013 and 2016 to 2019 while in 2013 to 2016 there was a decline. This shows that more and more companies are choosing the capital market as a place to collect company funds.

When conducting an initial offering the company expect to gain maximum funds, but a phenomenon that often occurs when companies go public is underpricing. Underpricing is a condition where the initial public offering price is set significantly lower than the price on the secondary market on the first day (Ritter, 1998). The underpricing phenomenon implies that companies get less than what they deserve based on the company's value that is actually perceived by the market (Sudarmaji, 2020). Underpricing is considered detrimental to issuers because the additional IPO proceeds obtained are not optimal because the initial public offering price is set too low (Beatty, 1989). But on the other hand, it benefits investors because investors can enjoy the return of buying shares owned (Aini, 2013).

Table 1. The level of underpricing IPOs in Indonesia 2010-2020

\begin{tabular}{cccc}
\hline Year & $\begin{array}{c}\text { Total Number } \\
\text { of IPOs }\end{array}$ & Underpricing & $\%$ \\
\hline 2010 & 23 & 22 & $96 \%$ \\
2011 & 25 & 17 & $68 \%$ \\
2012 & 27 & 25 & $93 \%$ \\
2013 & 33 & 25 & $76 \%$ \\
2014 & 23 & 20 & $87 \%$ \\
2015 & 17 & 15 & $88 \%$ \\
2016 & 15 & 14 & $93 \%$ \\
2017 & 36 & 33 & $92 \%$ \\
2018 & 55 & 54 & $98 \%$ \\
2019 & 55 & 54 & $98 \%$ \\
2020 & 51 & 48 & $94 \%$ \\
\hline
\end{tabular}




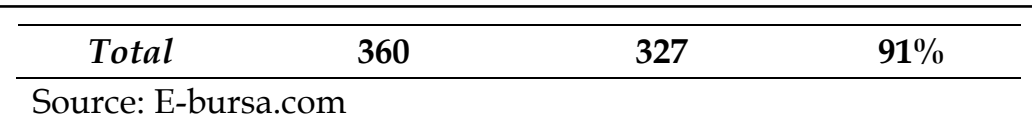

The data shows that the underpricing rate reached $>90 \%$ of the total companies conducting Initial public offerings in Indonesia from 2016 to 2020. It was found again in the data that the underpricing rate decreased from 2019 to 2020 by $4 \%$.

The data shows that the underpricing rate reached $91 \%$ of the total companies conducting Initial Public Offerings in Indonesia from 2010 to 2020. This high level of underpricing indicates that companies conducting Initial Public Offerings in Indonesia did not raise their funds optimally.

Prices in the Secondary Market are formed from the demand and supply by investors. Where investors in making investment decisions through various aspects that must be considered. A decision taken by investors by looking at existing signals is called Signaling Theory. Information received by investors will be interpreted and analyzed first whether the information is considered a positive signal (good news) or a negative signal (bad news) (Jogiyanto, 2010)

Macroeconomics is one of the signals that investors pay attention to, such as inflation, IDX composite index, GDP. For example, an increase in inflation will cause a decrease in people's purchasing power for goods and services produced by companies. This resulted in the level of sales decreased, which in turn reduced the level of profit earned by the company. A decrease in the profit of a company reduces the interest of investors to invest in the company (Darmadji, 2006). Then an increasing GDP indicates a growing economy and has many opportunities to increase company sales (Bodie, 2014). The increase in income will affect the company's productivity and its performance in the capital market. This will encourage investors to make investments which then have an impact on the capital market (Tandelilin, 2007). Then the value of the IDX Composite Index also affects the decision of investors to buy shares which affects stock prices in the secondary market.

Research on underpricing during Initial Public Offering has been widely carried out both in Indonesia and abroad. Research conducted by Adnyana \& Imawati (2017) shows that inflation does not significantly affect underpricing in Indonesia, but according to Manurung (2020) and Thoriq et al. (2018) states that inflation affects underpricing of companies conducting IPOs in Indonesia.

Research by Gunturkun et al. (2012) found that the ISE 100 index (Turkish Stock Index) did not affect underpricing in the IPO, while the research of Tran \& Jeon (2011) found different results on the S\&P 500 index (Index of 500 stocks in the United States), namely the S\&P Index influenced underpricing during the IPO.

Breinlinger and Glogova (2002) examined the relationship between IPOs and macroeconomic factors such as gross domestic product (GDP) growth using annual observations of IPO volumes for six continental European countries. The research shows that neither interest rates nor GDP growth exhibit any significant influence on underpricing. Gunturkun et al (2012) also show the same result on IPO in Turkey.

The high level of underpricing during the IPO, the differences in results in previous studies and the limited research on certain variables in Indonesia encourage research on the factors that influence underpricing at the time of Initial Public Offering. Based on this, this research will be conducted to analyze the effect of macroeconomic factors: inflation, IDX Composite Index and GDP on underpricing in Indonesia in 2010-2020.

\section{LITERATURE REVIEW}

Research on the underpricing phenomenon in companies conducting IPOs that are used as references comes from journals that have researched this before. Some of them have similarities but also differences in the variables used.

Inflation is an increase in the price of the product as a whole. Inflation is a negative signal for investors. High inflation values can reduce investors' interest in investing in stocks. As a result, the demand for shares in the secondary market will decrease, resulting in an increase in stock prices lead to underpricing. The research of Imawati \& I Made Adnyana (2017) examining macroeconomics, namely inflation and exchange rates. The results show that the inflation rate has no significant effect on the level of underpricing and the exchange rate has a positive and significant effect on the level of underpricing. Thoriq et al. (2018) with internal and external variables show that inflation variable effect underpricing. Then the research conducted by Manurung (2020) which examined the underpricing that occurred in Indonesia in the period 2000-2018, using the vector autoregressive method found that inflation, initial return lag one and 
two, oil prices affected underpricing in the Indonesian capital market. Thus, the hypothesis proposed in this study is as follows:

$\mathrm{H}_{1}$ : Inflation has a negative effect on the level of underpricing

The IDX Composite Index is one of the indices that local and foreign investors pay attention to when investing in the Indonesia Stock Exchange (IDX) because the IDX Composite Index contains all shares listed on the IDX. Thus, an investor can see whether market conditions are increasing or decreasing through the IDX Composite Index movement. A high IDX Composite Index value will be a positive signal for investors to share prices that will encourage investors' interest. High investor interest will be realized by increasing the purchase of shares resulting in an increase in the frequency of transactions in the secondary market. Tran \& Jeon (2011) investigated the dynamic impact of macroeconomic conditions on IPOs in the United States from 1970 to 2005, using cointegration test, vector error correction (VEC) model, Ordinary Least Squares (OLS) regression, multivariate, Vector Autoregressive model (VAR), Impulse Response Function (IRF) analysis as a time-series econometric technique. The results show that there is a long-term equilibrium relationship between IPO underpricing and selected macroeconomic variables such as IP index, S\&P 500 index, CPI. Thus, the hypothesis proposed in this study is as follows:

$\mathrm{H}_{2}$ : IDX Composite Index has a positive effect on the level of underpricing

The high value of GDP indicates the growth of people's income, and then the increasing income of the people will increase the demand for goods and services. Then the company's profits will increase and this will encourage more investment. In other words, in the long term if GDP increases, investment will also increase (Sukirno, 2011). This increase in investment will increase the demand for or purchase of shares in the secondary market. It's affecting secondary market because in the secondary market stock prices formed by investors demand while in the primary market the price is set by underwriter analyst. Güntürkün (2012) examines the effect of macroeconomic variables on underpricing during IPOs in Turkey, using the ISE 100 index, consumer price index, consumer confidence index, interest rate, world oil price, GDP per capita on the first day performances of IPOs variables. The results showed that the ISE 100 index, consumer price index, interest rate, GDP per capita did not affect underpricing. Thus, the hypothesis proposed in this study is as follows:

$\mathrm{H}_{3}$ : GDP has a positive effect on the level of underpricing

Various research results that are inconsistent with the factors that influence the underpricing phenomenon and the limited research on certain variables in Indonesia encourage research to be carried out again to test the consistency of the dependent variable in influencing underpricing.

\section{RESEARCH METHOD}

The data analysis method used to analyze the variables in the study is multiple linear regression analysis with the help of the SPSS application. Multiple linear regression analysis was used to determine the effect of two or more independent variables on the dependent variable. Regression analysis used in this study is panel data regression, which is a combination of time series and cross section data. Statistical analysis carried out included classical assumption test, F statistical test (model feasibility test), $\mathrm{t}$ statistic test (individual parameter significance test) and coefficient of determination test (R2).

The source of data in this study comes from secondary data, namely data that comes from other parties and is collected or processed into a form of information for analysis purposes.

Quantitative data in this study include:

1. Data on the selling price of shares at the time of the IPO (opening price) and the closing price of shares (closing price) on the first day of listing on the Indonesia Stock Exchange (IDX). This data is used to calculate the level of underpricing which is interpreted by the initial return value. Stock price data is obtained from the official website of the Indonesia Stock Exchange and e-bursa

2. Indonesia's inflation rate data for the period 2010 - 2020 obtained from the Central Statistics Agency website

3. Data on Indonesia's Gross Domestic Product (GDP) obtained from the website of the Central Statistics Agency

4. Composite Stock Price Index (CSPI) data obtained from Yahoo Finance 
Underpricing in the IPO is indicated by the Initial Return variable, which is the positive difference between the stock price on the first day of closing in the secondary market (closing price) and the stock price at the initial offering (offering price) divided by the initial offering share price. (Hartono 2014)

\section{IR $=($ Closing Price - Offering Price $) /$ Offering Price $\times 100 \%$}

The analytical tool used in this research is multiple regression analysis (Multiple Regression Analysis). In the calculation, the data will be analyzed using data processing through the SPSS program. The multiple regression equation that will be formed in this study is as follows:

$$
Y=\beta_{1} X_{1}+\beta_{2} X_{2}+\beta_{3} X_{3}
$$

Description ;

$Y=$ Underpricing (Initial Return)

$\beta_{1} X_{1}$ Inflation variable

$\beta_{2} X_{2}=$ GDP variable

$\beta_{3} X_{3}=$ IDX Composite Index variable

\section{RESULT AND DISCUSSION}

The data analysis technique used was the classic assumption test, multiple linear regression analysis, and hypothesis testing. Data passed all the requirements of classical assumption in order to proceed multiple regression analysis (The detailed results of the tests are in the Appendix section).

Inflation variable has a coefficient value of -0.031 , this indicates that inflation has a negative effect on underpricing that occurs in Indonesia, where each addition of the inflation variable by 1 unit, it will reduce the level of underpricing by 0.031 assuming the other variables are constant. Based on this analysis, it is concluded that $\mathrm{H} 0 ; \beta 1=0$ rejected and accepted $\mathrm{H} 1: \beta 1 \neq 0$. This indicates that inflation has a significant negative effect on underpricing.

Based on the results of the study, inflation has a significant effect on the level of underpricing, indicating that when Indonesia's inflation rate is high, it will reduce investor interest in buying shares. An increase in inflation will result. increase in the prices of goods as a whole, the increase in those prices will. affect the level of domestic production. which will have an impact on the production of export goods to decline. This can make investors not buy too many shares for fear of experiencing losses in the future (Baskara, 2017). This resulted in low demand for shares, thereby lowering stock prices in the secondary market which led to underpricing. If inflation increases, the interest rate will also increase. This increase in interest rates will attract people to save in banks. This condition causes savings interest rates to be higher than usual and exceed the rate of return on investment in the capital market. As a result, investment in the capital market becomes unattractive to investors and they prefer to shift their funds to savings (Darmadji, 2006). This result is in accordance with research conducted by Manurung (2020) which concluded that inflation has a significant effect on underpricing during IPO offerings.

The IDX Composite Index variable has a coefficient value of 1.135, this indicates that the IDX Composite Index has a positive effect on underpricing that occurs in Indonesia, where each addition of the inflation variable by 1 unit, it will increase the level of underpricing by 1.135 assuming the other variables are constant. Based on this analysis, it is concluded that $\mathrm{H} 0 ; \beta 1=0$ rejected and accepted $\mathrm{H1}: \beta 1 \neq 0$. This shows that inflation has a significant positive effect on underpricing.

Based on the research results, the IDX Composite Index value has a significant effect on the level of underpricing, which indicates that when the IDX Composite Index is high or rising, it will give a positive signal to investors regarding stock movements in Indonesia. Positive signals received by investors encourage high interest in buying shares. These results show the same results as research by Tran and Joen (2011) on stock indexes in the USA, namely the S and P 500 Index, which affect the underpricing that occurs.

The GDP variable has a coefficient value of 0.024 , this indicates that GDP has a positive effect on underpricing that occurs in Indonesia, where each additional GDP variable is 1 unit, it will increase the level of underpricing by 0.024 assuming the other variables are constant. that $\mathrm{H} 0 ; \beta 1=0$ rejected and accepted $\mathrm{H} 1: \beta 1 \neq 0$. This shows that inflation has a significant positive effect on underpricing.

Based on the results of the study, the value of GDP has a significant effect on the level of underpricing which indicates that when GDP is high or rising, it will affect the decision to buy shares for 
investment through shares. High GDP will have an effect on increasing people's income, and then the higher people's income will increase the demand for goods and services. Then the company's profits will increase and this will encourage more investment. In other words, in the long term if GDP increases, investment will also increase (Sukirno, 2011). Increasing the amount of GDP in a country not only. increase the amount of investment in buying shares but will also increase the amount of investment in selling shares in Indonesia. With this increase will reduce the occurrence or level of underpricing that occurs. These results show different results from research by Gunturkun (2012) in Turkey where Turkey's GDP does not affect the underpricing that occurs in Turkey.

Coefficient of Determination Shows the proportion of variation in the dependent variable that can be explained by the independent variable. $\mathrm{R}^{2}$ will not decrease in value if there are new variables added to the model. Therefore, if the model contains many variables, then $\mathrm{R}^{2}$ will also produce a large value. A good model has a large $R^{2}$ value or close to 1 . Adjusted $R^{2}$ is a correction to $R^{2}$, meaning that the adjusted $R^{2}$ value can increase or decrease if there are additional variables into the model. Adjustment of adjusted $\mathrm{R}^{2}$ : For $x$ ( var. predictor ) $>1$, adjusted $\mathrm{R}^{2}<\mathrm{R}^{2}$. If the number of independent variables is added, then adjusted $\mathrm{R}^{2}$ increases with the amount of increase less than $\mathrm{R}^{2}$.

In general, if there are additional independent variables that are good or significant predictors, the variance will increase so that the adjusted $\mathrm{R}^{2}$ will increase. Meanwhile, if the additional independent variable does not increase the variance, the adjusted $\mathrm{R}^{2}$ will decrease, which indicates that the added variable is not a good predictor. A good model if adjusted $\mathrm{R}^{2}$ is large.

Table 2 Model Summary

\begin{tabular}{cccccc}
\hline Model & $\mathrm{R}$ & R Square $^{\mathrm{b}}$ & $\begin{array}{c}\text { Adjusted R } \\
\text { Square }\end{array}$ & $\begin{array}{c}\text { Std Error of } \\
\text { the Estimate }\end{array}$ & $\begin{array}{c}\text { Durbin- } \\
\text { Watson }\end{array}$ \\
\hline 1 & $.882^{\mathrm{a}}$ & .778 & .776 & .21873 & 1.884 \\
\hline
\end{tabular}

Based on the SPSS output above, it shows that the $\mathrm{R}^{2}$ number is 0.778 . This shows that the independent variable is able to explain the dependent variable, in this case the IR variable is $77.8 \%$ while the remaining $22.2 \%$ is influenced by other variables not explained in the research model.

\section{CONCLUSIONS AND SUGGESTIONS}

This study shows the underpricing phenomenon at the time of the IPO in 2010-2020 in Indonesia. Then this phenomenon is seen from the macroeconomic impact of inflation, IDX composite index and GDP on the level of underpricing that occurs. Based on the research that has been done, it can be concluded that: first, The average level of underpricing in Indonesia for companies conducting IPOs in 2010-2020, namely 360 companies, is $91 \%$. With the highest underpricing rate in 2018 and 2019 at $98 \%$ and the lowest underpricing rate in 2011 at $68 \%$. Second, Macroeconomics, namely Inflation, IDX composite index and GDP through the $\mathrm{T}$ test showed a significant influence on the underpricing that occurred in Indonesia in 2010-2020. Third, inflation variable negatively and significantly affects the underpricing that occurs in Indonesia, where each addition of the inflation variable by 1 unit, it will reduce the level of underpricing by 0.031 by assuming the other variables are constant. Fourth, the IDX Composite Index variable has a positive and significant effect on the underpricing that occurs in Indonesia, where each additional 1 unit of the IDX Composite Index variable will increase the level of underpricing by 1.135 assuming the other variables are constant. Fifth, the GDP variable positively and significantly affects the underpricing that occurs in Indonesia, where each additional 1 unit of the GDP variable will increase the level of underpricing by 0.024 assuming the other variables are constant. Sixth, macroeconomic variables (inflation, IDX composite index, GDP) are able to explain the dependent variable in this case the IR variable (underpricing level) of $77.8 \%$ while the remaining $22.2 \%$ is influenced by other variables not explained in the research model.

Based on the results of research, issuing companies or securities need to consider macroeconomic factors when assessing and determining the offering share price at IPO. This will help minimize the level of underpricing that occurs. The empirical results reported herein should be considered in light of some limitations. In this study, we only examine 10 years with relatively stable economic conditions. We advise for the next research to also look at the microeconomic factors that influence IPO underpricing, expanding the range of research periods or period based on the economic fluctuations and financial crises to obtain robust results that would lead to a better understanding of the underpricing phenomenon. 


\section{REFERENCES}

Ahmad S. 2018. Analysis of Initial Stock Underpricing Phenomenon at Indonesia. Stock Exchange. Journal Economic and Business of Islam. 3(1): 69-90.

Aini SH. 2013. Faktor yang mempengaruhi underpricing saham pada perusahaan IPO di BEI periode 20072011. Jurnal Ilmiah Manajemen 1(1): 88-102.

Baskara Y, Sulasmiyati S. 2017. Pengaruh Faktor Fundamental Makroekonomi terhadap Keputusan Investasi Saham oleh Investor Asing di Indonesia. Jurnal Administrasi Bisnis 47(1) : 130-139

Beatty N, Ritter J. 1986. Investment Banking Reputation and Underpricing of Initial Public Offering; Journal of Financial Economics, Vol. 15; pp. 213 - 232.

Breinlinger, Glogova. 2002. Determinants of Initial Public Offerings: A European Time-Series Cross-Section Analysis. Oesterreichische Nationalbank Financial Stability Report,3 : 87-106.

Bodie, Kane, dan Marcus. 2014. Manajemen Portofolio dan Investasi. Edisi 9-Buku 2. Jakarta: Salemba Empat.

Darmadji T, Fakhruddin HM. 2015. Pasar Modal di Indonesia. Jakarta (ID): Salemba Empat.

Ghozali I. 2016. AplikasiAnalisis Multivariete dengan Program IBM SPSS 23 (Edisi 8). Semarang (ID): Badan Penerbit Fakultas Ekonomi (BPFE).

Gujarati, Damodar, Porter, Dawn C, Mardanugraha, Eudenia. 2015. Dasar-Dasar Ekonometrika. Jakarta (ID): Salemba Empat.

Gunturkun HM, Guarda S, Erdogan HH. 2012. Impact of Macroeconomic Factors on Underpricing of Initial Public Offerings before and after the Recent Global Financial Crisis: Evidence from Istanbul Stock Exchange. Journal of Applied Finance dan Banking. 2(5): 261-273.

Hasyim, Ali Ibarhim. 2017. EKONOMI MAKRO Edisi Pertama Cetakan ke-2. Depok: KENCANA

Hartono, Jogiyanto. 2014. Teori Portofolio dan Analisis Investasi. Yogyakarta (ID): BPFE Yogyakarta.

Imawati, Adnyana MI. 2017. Pengaruh Faktor-Faktor Mikro Dan Makroekonomi Terhadap Tingkat Underpricing Pada Saat Initial Public Offering (IPO). Jurnal Ilmu Manajemen 13 (2) : 72-86.

Jawangga Y H.2002. Dasar-dasar Manajemen, Klaten: Cempaka putih.

Jogiyanto, H.M. (2010). Teori Portofolio dan Analisis Investasi. Edisi Ketujuh. BPFE. Yogyakarta.

Kuncoro, Mudrajad. 2008. Otonomi dan Pembangunan Daerah: Reformasi, Perencanaan, Strategi dan Peluang. Jakarta: Erlangga

Larasati D, Irwanto AK, Permanasari Y. 2013. Analisis strategi optimalisasi portofolio saham LQ 45 (pada Bursa Efek Indonesia Tahun 2009-2011). Jurnal Manajemen dan Organisasi 4(2): 164- 171.

Manurung HA, Manurung CJ. 2019. Macroeconomic Variables, International Journal of Civil Engineering and Technology, 10(4), 2019, pp. 583-589.

Samsul M. 2006. Pasar Modal dan Manajemen Portofolio. Surabaya: Penerbit Erlangga.

Sudarmaji E, Ambarwati S. 2020. Event Study of IPO in Indonesia : Pump and Dump \& Flipping Strategy Analysis. Journal of Accounting and Finance Management 1 (1): 81-94.

Sukirno, Sadono. 2004. Makroekonomi Teori Pengantar. Jakarta: PT RajaGrafindo Persada.

Thariq NK, Hartoyo S, Sasongko H. 2018. Faktor Internal dan Eksternal yang Mempengaruhi Underpricing pada saat IPO di Bursa Efek Indonesia. Jurnal Aplikasi Manajemen dan Bisnis 4(1): 19-31.

Tran and Jeon, The dynamic impact of macroeconomic Factors on initial public Offerings: Evidence from time-series analysis, Applied Economics,43(23), (2011), 3187-3201.

Trisnaningsih S. 2005. Analisis Faktor-Faktor yang Mempengaruhi Tingkat Underpricing pada Perusahaan yang Go Public di Bursa Efek Jakarta. Jurnal Akuntansi dan Keuangan. 4(2): 195-210.

Utaminingsih, Arni, Eduardus Tandelilin, Suad Husnan dan R. Agus Sartono. (2013). Asymmetric Information In The IPO Underpricing Process On The Indonesia Stock Exchange: Pricing, Initial Allocation, Underpricing and Price Stabilization. Journal of Indonesian Economy and Business, Vol. 28 No.3, pp. 311-321

Widarjono A. 2009. Ekonometrika Pengantar dan Aplikasinya. Yogyakarta (ID): Ekonisia.

[YAHOO] Yahoo Finance. 2021. Jakarta Composite Index (^JKSE) [internet]. [diakses 2021 Apr 7]. Tersedia pada: https:// finance.yahoo.com/. 
Yolana, Chastina, Martani D. 2005. Variabel-Variabel yang Mempengaruhi Fenomena Underpricing pada Penawaran Saham Perdana di BEJ tahun 1994- 2001. Simposium Nasional Akuntansi VII Solo. 538553

\begin{tabular}{|c|c|c|c|c|}
\hline \multirow{2}{*}{ APPENDIX } & \multicolumn{3}{|c|}{$\begin{array}{l}\text { Unstandardized } \\
\text { Residual }\end{array}$} & \\
\hline & $\mathrm{N}$ & & 324 & \\
\hline \multirow{2}{*}{$\begin{array}{l}\text { Normality test } \\
\text { Normality }\end{array}$} & Normal Parametersa,b & Mean & -.0014069 & \\
\hline & & Std. Deviation & .21805189 & test is used to test \\
\hline whether the & Most Extreme & Absolute & .092 & residual value \\
\hline $\begin{array}{l}\text { generated from } \\
\text { normally }\end{array}$ & Differences & Positive & .043 & $\begin{array}{l}\text { the regression is } \\
\text { distributed or not }\end{array}$ \\
\hline (Ghozali, 2017). & & Negative & -.092 & \\
\hline Table 3 & Test Statistic & & .092 & Normality Test \\
\hline Results & Asymp. Sig. (2-tailed) & & $.105^{c}$ & \\
\hline
\end{tabular}

Source: SPSS output processed 2021

The normality test was conducted to determine whether the residuals were normally distributed or not. In this test, there are 2 hypotheses, namely the residuals are normally distributed, as the main hypothesis (H0), and the residuals are not normally distributed, as the alternative hypothesis (H1). Used alpha (a) of 0.05 at the level of significance. The main hypothesis (H0) will be rejected if the P-value is less than the value of $a$. From the resulting output, the value of Asymp.Sig (0.105) is greater than a, so H0 is not rejected, it can be concluded that the residuals of the regression model are normally distributed.

\section{Multicollinearity Test}

Multicollinearity test was conducted to test whether there is a correlation or relationship between independent variables in the related regression model. A good regression model should not have a correlation between the existing independent variables or it can be said that there are no symptoms of multicollinearity. In this case, the Tolerance and VIF values of each independent variable will be used to determine the presence or absence of multicollinearity symptoms in this regression model.

Table 4 Multicollinearity Test Results

\begin{tabular}{|c|c|c|c|c|c|c|c|}
\hline \multicolumn{8}{|c|}{ Coefficient ${ }^{\mathrm{a}, \mathrm{b}}$} \\
\hline \multirow[t]{2}{*}{ Model } & \multicolumn{2}{|c|}{$\begin{array}{c}\text { Unstandardized } \\
\text { Coefficients }\end{array}$} & \multirow{2}{*}{$\begin{array}{c}\begin{array}{c}\text { Standardized } \\
\text { Coefficients }\end{array} \\
\text { Beta }\end{array}$} & \multirow[t]{2}{*}{$\mathrm{t}$} & \multirow[t]{2}{*}{ Sig. } & \multicolumn{2}{|c|}{ Collinearity Statistic } \\
\hline & $\mathrm{B}$ & Std. Error & & & & Tolerance & VIF \\
\hline Inflasi & -.031 & .007 & -.294 & -4.550 & .000 & -.165 & 6.066 \\
\hline IDX CI & 1.135 & .072 & .898 & 15.786 & .000 & .213 & 4.691 \\
\hline PDB & .024 & .007 & .256 & 3.572 & .000 & .134 & 7.460 \\
\hline
\end{tabular}

Source : SPSS output processed 2021

Based on the SPSS output above, it can be seen that the Tolerance value is $0.165 ; 0.213 ; 0.134$ where the entire Tolerance value is $>0.1$ and the VIF value is $6.066 ; 4,691 ; 7,460$ where all VIF values are $<10$ so it can be said that there is no multicollinearity symptom. Keep in mind that the regression model will be said to be good if the model does not experience symptoms of multicollinearity because regression analysis focuses on the relationship between each independent variable and the dependent variable.

\section{Heteroscedasticity Test}

To detect the presence or absence of heteroscedasticity using the Glejser test. If it is found that the independent variable significantly affects the dependent variable, it can be said that there is an indication of heteroscedasticity. 
Table 5 Heteroscedasticity Test Results

Coefficient $^{\mathrm{a}}$

\begin{tabular}{lccccc}
\hline \multirow{2}{*}{ Model } & \multicolumn{2}{c}{ Unstandardized Coefficients } & $\begin{array}{c}\text { Standardized } \\
\text { Coefficients }\end{array}$ & \multirow{2}{*}{$\mathrm{t}$} & Sig. \\
\cline { 2 - 4 } & $\mathrm{B}$ & Std. Error & Beta & & \\
\hline Inflasi & .007 & .005 & .105 & 1.445 & .150 \\
IDX CI & -.128 & .124 & -.065 & -1.029 & .304 \\
PDB & .010 & .004 & .167 & 2.649 & .108 \\
\hline
\end{tabular}

Source : SPSS output processed 2021

Based on the SPSS output above, it can be seen that the P-Value (Sig.) is $0.150 ; 0.304 ; 0.108$ where the entire value of the independent variable is $>a=0.05$ so it can be said that there is no heteroscedasticity symptom. Keep in mind that the regression model will be said to be good if the model does not experience symptoms of heteroscedasticity or homoscedasticity.

\section{Autocorrelation Test}

In this study, the autocorrelation test aims to determine whether there is a correlation between the confounding variable in a certain period and the previous variable. (Ghozali, 2017) To detect the presence or absence of autocorrelation in this study, Durbin Watson was used. The following are the results of the resulting autocorrelation test.

Autocorrelation Test

Table

\begin{tabular}{|l|l|}
\hline Durbin-Watson stat & 1.884 \\
\hline
\end{tabular}

Based on the table above, Durbin Watson's result is 1.884. It is also known that the number of samples (n) is $>200$ and the number of predictors in the best model (k) is 3 . The results of the study refer to the Durbin Watson criteria as shown in the following table.

Table 6 Autocorrelation Test Results

\begin{tabular}{cccc}
\hline $\mathrm{H}_{0}$ & Desicion & If $\mathrm{H}_{0}$ & Conclusion \\
\hline No autocorrelation $(+)$ & Reject $\mathrm{H}_{0}$ & $0 \leq \mathrm{d} \leq \mathrm{dL}$ & $\begin{array}{c}\text { Autocorrelation } \\
(+)\end{array}$ \\
\hline No autocorrelation $(+)$ & No Decision & $\mathrm{dL} \leq \mathrm{d} \leq \mathrm{dU}$ & - \\
\hline $\begin{array}{c}\text { There is no autocorrelation }(+) \\
\text { nor }(-)\end{array}$ & Does not reject $\mathrm{H}_{0}$ & $\mathrm{dU} \leq \mathrm{d} \leq 4-\mathrm{dU}$ & No autocorrelation \\
\hline No autocorrelation $(-)$ & Reject $\mathrm{H}_{0}$ & $4-\mathrm{dL} \leq \mathrm{d} \leq 4$ & Autocorrelation $(-)$ \\
\hline No autocorrelation $(-)$ & No Decision & $4-\mathrm{dU} \leq \mathrm{d} \leq 4-\mathrm{dL}$ & - \\
\hline Source : SPSS output processed 2021 & &
\end{tabular}

(1)

(2)

(3)

(5)

(4)

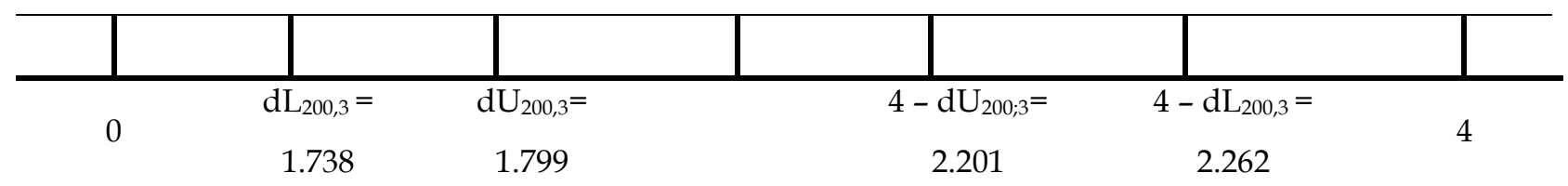

Decision value making is carried out with the provisions of $\mathrm{dU}<\mathrm{d}<4$-dU or $(1.799<1.884<2.201)$ is in decision area 3, so it can be concluded that the null hypothesis is not rejected which states that there is no positive or negative autocorrelation (as seen from the autocorrelation decision table). ) or it can be concluded that there is no autocorrelation. Thus, the autocorrelation problem has been met, so that further multiple linear regression analysis can be carried out.

\section{Model Fit Test (F Test)}

Hypothesis

H0 : $\beta_{1}=\beta_{2}=\beta_{\mathrm{k}}=0$ (model is not suitable for use)

$\mathrm{Ha}$ : there is at least one $\beta \mathrm{i} \neq 0$ (the model is suitable for use) 
$\mathrm{H} 0$ is rejected if $\mathrm{P}-$ Value $<\mathrm{a}$

Table 7 F Test Results

\begin{tabular}{cccccc}
\multicolumn{7}{c}{ ANOVA, } \\
\hline \multirow{2}{*}{ Model } & $\begin{array}{c}\text { Sum of } \\
\text { Squares }\end{array}$ & df & Mean Square & F & Sig. \\
\hline Regression & 53.930 & 3 & 17.977 & 375.727 & $.000^{\mathrm{c}}$ \\
Residual & 15.358 & 321 & .048 & & \\
Total & $69.288^{\mathrm{d}}$ & 324 & & & \\
\hline
\end{tabular}

Source : SPSS output processed 2021

Based on the results of the test statistics in the third step and the critical area in the fourth step, it can be seen that the P-Value value from the ANOVA table is 0.000 so that it meets P-Value $<\alpha(0.05)$ it can be concluded that $\mathrm{HO}$ is rejected so that the model is indeed feasible to use. or it can be said that the regression model is fit.

\section{Partial Test (t Test)}

Hypothesis:

$\mathrm{HO}: \beta_{0}=0$ (the coefficient is not significant in the model)

Ha: $\beta_{0} \neq 0$ (significant coefficient in the model)

$\mathrm{H} 0$ is rejected if $\mathrm{P}$-Value $<\mathrm{a}$

$\mathrm{a}=0.05$

Table 8 T Test Results

Coefficient ${ }^{\mathrm{a}, \mathrm{b}}$

\begin{tabular}{|c|c|c|c|c|c|c|c|}
\hline \multirow{2}{*}{ Model } & \multicolumn{2}{|c|}{$\begin{array}{c}\text { Unstandardized } \\
\text { Coefficients }\end{array}$} & \multirow{2}{*}{$\begin{array}{c}\text { Standardized } \\
\text { Coefficients } \\
\text { Beta }\end{array}$} & \multirow[b]{2}{*}{$\mathrm{t}$} & \multirow{2}{*}{ Sig. } & \multicolumn{2}{|c|}{$\begin{array}{l}\text { Collinearity } \\
\text { Statistic }\end{array}$} \\
\hline & B & $\begin{array}{l}\text { Std. } \\
\text { Error }\end{array}$ & & & & Tolerance & VIF \\
\hline Inflasi & -.031 & .007 & -.294 & -4.550 & , 000 & .165 & 6.066 \\
\hline IDX CI & 1.135 & .072 & .898 & 15.786 & 000 & 213 & 4.691 \\
\hline PDB & .024 & .007 & .256 & 3.572 & ,000 & .34 & 7.460 \\
\hline
\end{tabular}

Source : SPSS output processed 2021

Based on the results of the test statistics in the third step and the critical area in the fourth step, it can be seen that all predictor variables of inflation, IDX CI, and GDP have P-Value $=0.000 ; 0.000 ; 0.000$ where < so that $\mathrm{H} 0$ is rejected so that all significant coefficients are in the regression model. In other words, all variables that have a significant effect on the IR variable in the regression model.

Regression Model Writing:

$$
Y=\beta_{1} X_{1}+\beta_{2} X_{2}+\beta_{3} X_{3}
$$

Model Interpretation:

$$
\text { IR }=-0.031 * \text { Inflation }+1.135 * \text { IDX Composite Index }+0,024 * \text { GDP }
$$

- $\beta_{1}=$ Each addition of 1 unit of inflation variable, it will decrease the IR variable by 0.031 by assuming the other variables are constant.

- $\quad \beta_{2}=$ Each additional 1 unit of the IDX CI variable, it will increase the IR variable by 1.135 by assuming the other variables are constant.

- $\quad \beta_{3}=$ Each additional 1 unit of GDP variable, it will increase the IR variable by 0.024 by assuming the other variables are constant. 